\title{
Dietary fat and reproduction in the post partum sow
}

\author{
H. van den Brand and B. Kemp \\ Adaptation Physiology Group, Wageningen Institute of Animal Sciences, Wageningen University and \\ Research Centre, PO Box 338, 6700 AH, Wageningen, The Netherlands
}

Lactating sows are not able to ingest sufficient energy to produce the large amount of milk they are presently capable of. Therefore, sows use a considerable amount of body reserves to maintain their milk production. Body weight loss is negatively associated with subsequent reproductive performance. Addition of fat to the diet is often used to increase energy intake during lactation. This review examines the effects of adding fat to the diet on subsequent reproductive performance. Fat may affect reproduction in three different ways; first, by increasing milk fat output. Higher milk fat output limits or even nullifies the effect of a higher energy intake on body weight loss in ad libitum fed sows. It has even been demonstrated that sows fed an isocaloric fat-rich diet lost more body reserves than sows fed a carbohydrate-rich diet. Second, fat-rich diets increase blood metabolite levels (non esterified fatty acids, ßhydroxybutyrate, urea), which might negatively impact reproductive performance. Third, fat-rich diets depress secretion of insulin and IGF-1, which directly or indirectly affects $\mathrm{LH}$, oestradiol and progesterone secretion and follicle development. We concluded that adding fat to the diet of lactating sows disrupts the balance between $\mathrm{C} 2$ and $\mathrm{C} 3$ compounds, which is necessary to run the Krebs cycle in an efficient way, and may negatively affect the sows' subsequent reproductive performance. Therefore, increasing energy intake during lactation might be accomplished better by adjusting other management procedures to support feed intake, such as housing temperature, water intake, and prevention of overfeeding in early lactation.

\section{Introduction}

Modern sows produce large litters and must produce sufficient milk to nurse all the piglets. Milk production greater than $10 \mathrm{~kg} /$ day is common nowadays (Toner et al., 1996; King et al., 1996; Auldist et al., 1998, 2000; Renaudeau and Noblet, 2001; McNamara and Pettigrew, 2002; Ramanau et al., 2004). Because feed intake capacity is limited, especially in primiparous sows, body reserves are used to maintain milk production (Van der Peet-Schwering et al., 1998). Sows, which lost severe amounts of body reserves had depressed reproductive performance, expressed as prolonged weaning to oestrus interval (WOI), and reduced subsequent litter size (Vesseur et al., 1994; Koketsu and Dial, 1997). Low feed intake during lactation was associated with suppressed follicle development (Zak et al., 1997a; Quesnel et al., 1998a; Van 
den Brand et al., 2000a), impaired oocyte maturation (Zak et al., 1997b), low ovulation rate (Zak et al., 1997a; Van den Brand et al., 2000a), lower plasma progesterone concentrations in the subsequent pregnancy (Kirkwood et al., 1987a), and higher embryonic mortality (Kirkwood et al., 1987b; Zak et al., 1997b). Thus, it is important to maximize energy intake during lactation. Effects of lactational feed intake on reproduction were extensively reviewed by Einarsson and Rojkittikhun (1993), Dourmad et al. (1994), Kemp (1998), Williams (1998) and Prunier and Quesnel (2000). In many studies, energy intake was increased by supplementing fat in the diet. However, it is disputable whether or not increasing the fat content of the diet has a positive effect on lactational body weight loss and subsequent reproductive performance. This review examines the effects of adding fat to the diet on subsequent reproductive performance at three levels: 1) lactational energy metabolism and body weight loss; 2) blood metabolite levels and 3) metabolic and reproductive hormones and subsequent reproductive performance.

\section{Effects of additional fat in the diet on energy metabolism and body weight loss}

Pettigrew and Moser (1991) summarized the effects of adding fat to the diet of lactating sows and concluded that metabolizable energy (ME) intake increased when sows were fed ad libitum (Table 1). The average ME intake increased by $5.19 \mathrm{MJ} / \mathrm{day}$, but lactational body weight change was equivocal. Energy intake increased in all 19 studies reviewed, but body weight loss increased in four of them. On average, adding fat resulted in only $1.5 \mathrm{~kg}$ less lactational body weight loss compared to controls. Schoenherr et al. (1989) confirmed these results, and found that, especially at high ambient temperatures, energy intake increased by adding fat to the diet. At $32^{\circ} \mathrm{C}, \mathrm{ME}$ intake increased by $8.8 \mathrm{MJ} /$ day by adding fat to the diet, whereas at $20^{\circ} \mathrm{C}$ this difference was only $2.5 \mathrm{ME} /$ day. However, at both temperatures, body weight loss was similar for the control and fat-added groups, suggesting that additional energy in the form of fat was used for purposes other than sparing body weight. The interaction between dietary energy source and environmental temperature is probably due to the higher efficiency of fat-rich diets, and thus, lower heat production (Babinszky, 1992; Van den Brand et al., 2000b). Drochner (1989) summarized 17 experiments in which 4 to $20 \%$ fat was added to the diet of lactating sows. Fat concentration in both colostrum and milk increased linearly with increasing dietary fat content; each percentage increase in dietary fat resulted in $0.5 \%$ increase in milk fat content. Assuming that milk production was $10 \mathrm{~kg} /$ day and feed intake was $5 \mathrm{~kg} / \mathrm{day}$, then all additional fat from the diet was likely secreted into the milk.

Table 1. Effect of adding fat to diets of ad libitum fed lactating sows (Pettigrew and Moser, 1991).

\begin{tabular}{|c|c|c|c|c|}
\hline & \multicolumn{2}{|c|}{ \# of comparisons } & \multirow[t]{2}{*}{ Response $(\mathrm{MJ} / \mathrm{d})$} & \multirow[t]{2}{*}{ Total \# of sows } \\
\hline & Positive & Negative & & \\
\hline \multicolumn{5}{|l|}{ ME intake $(\mathrm{MJ} / \mathrm{d})$} \\
\hline Added fat during lactation & 19 & 0 & $5.19 \pm 0.75$ & 834 \\
\hline$\geq 10 \%$ added fat & 9 & 0 & $6.48 \pm 1.67$ & 317 \\
\hline$<10 \%$ added fat & 10 & 0 & $4.39 \pm 0.67$ & 517 \\
\hline Lactational weight change $(\mathrm{kg})$ & 11 & 4 & $1.5 \div 0.7$ & 697 \\
\hline \multicolumn{5}{|l|}{$\mathrm{ME}$ intake increase } \\
\hline$\geq 4.2 \mathrm{MJ} / \mathrm{day}$ & 5 & 2 & $2.2 \pm 1.1$ & 239 \\
\hline$<4.2 \mathrm{Ml} / \mathrm{day}$ & 7 & 3 & $1.3 \pm 0.9$ & 584 \\
\hline
\end{tabular}

- Number of studies which found a positive or negative effect of fat addition on ME intake or lactational body weight change compared to a control group. 
The higher body weight loss in fat fed sows was confirmed in studies in which sows were fed isocaloric diets, which differed in fat content. Babinszky (1992) compared a corn starch diet (3.7\% fat) with an animal fat diet $(12.5 \%$ fat). Milk energy output was higher $(51.0 \mathrm{vs} 44.8 \mathrm{MJ} /$ day) and body fat loss was greater in sows fed the fat-rich diet than for sows fed the corn starch diet (506 vs $381 \mathrm{~g} /$ day), resulting in a more severe negative energy balance for this group of sows (-20.8 vs -14.7 MJ/day). Van den Brand et al. (2000b) demonstrated that this effect depended on the level of energy intake (Table 2). At a low level of energy intake, there were no differences in milk fat content or body fat loss for sows fed a starch (3.1\% fat) or fat-rich (11.0\% fat) diet, but at a high level of energy intake, fat content in the milk and body fat loss were greater in sows fed a fat-rich diet than in sows fed a starch-rich diet. The greater body fat loss in sows fed the fat-rich diet was probably due to the lack of sufficient blood glucose in these sows, which was also reflected in a somewhat lower milk lactose concentration. Therefore, glycerol from body reserves was used for gluconeogenesis, resulting in mobilization of body reserves. In addition, Lauridsen and Danielsen (2004) demonstrated that lactational body weight loss depends on the fat source used. Six treatment diets were prepared by adding $8 \%$ of one of 6 different fat sources to the control diet. Although not significant, body weight loss during a 28day lactation period ranged from 2.7 (fish oil) to 11.0 (sunflower oil) kg, with $6.7 \mathrm{~kg}$ body weight loss for the control group. However, milk fat output (kg/day) was significantly higher in some fat supplemented diets compared to the control group. Thus, in most studies (Averette et al., 1999; Tilton et al., 1999a; Jones et al., 2002; Lauridsen and Danielsen, 2004), addition of fat to sow diets resulted in higher milk fat output, whereas effects on lactational body weight loss were negligible or absent.

Table 2. Effect of lactational energy intake and type of diet on milk production and energy balance of primiparous sows (Van den Brand et al., 2000b).

\begin{tabular}{|c|c|c|c|c|}
\hline \multirow{2}{*}{$\begin{array}{l}\text { Energy intake (M) NE/d) } \\
\text { Diet type }\end{array}$} & \multicolumn{2}{|c|}{ High: 44} & \multicolumn{2}{|c|}{ Low: 33} \\
\hline & Fat & Starch & Fat & Starch \\
\hline Milk production $(\mathrm{kg} / \mathrm{d})$ & $9.6^{a}$ & $9.9^{\mathrm{a}}$ & $8.0^{\mathrm{b}}$ & $8.6^{b}$ \\
\hline Milk fat $(\%)$ & $8.4^{\circ}$ & $6.9^{b}$ & $7.6^{2 b}$ & $7.8^{2 b}$ \\
\hline Protein gain (g/d) & .50 & -31 & -69 & -75 \\
\hline Fat gain $(g / d)$ & $-568^{2}$ & $-401^{b}$ & $-511^{2}$ & $-521^{2}$ \\
\hline
\end{tabular}

ab Values within a row lacking a common superscript differ $(P<0.05)$.

\section{Glucose and fat intermediary metabolism pathways}

Based on results mentioned above, we suggest that the indirect effects of fat-rich diets on reproduction via lowering the mobilization of body reserves are limited. On the other hand, fat-rich diets probably alter intermediary metabolism, and thereby, affect reproductive performance. During lactation, sows lose body reserves, which mainly consist of fat. Fat consists of C2-compounds (two carbon atom fragments), which are precursors for production of acetylCoA. Acetyl-CoA, together with oxaloacetate from $\mathrm{C} 3$ compounds (three carbon atom fragments), in a ratio of $1: 1$, is necessary to run the Krebs cycle. At the same time, sows are producing milk, the amount of which is largely determined by the availability of lactose (Boyd et al., 1995). Because glucose (C3) is the main precursor of lactose, lactation results in decreased availability of $\mathrm{C} 3$ compounds. The state of negative energy balance is characterized by elevated blood non-esterified fatty acids (NEFAs). In the liver, NEFAs are normally oxidized or esterified into triglycerides. Triglycerides are stored in the liver or exported as part of a very 
low-density lipoprotein (VLDL) for metabolism by extra-hepatic tissue, such as the mammary gland, which secretes them as milk fat. Oxidation of NEFAs may be complete, via acetyl-CoA or incomplete resulting in production of ketone bodies, e.g. B-hydroxybutyrate (BHBA). This pathway has been investigated less in sows than in cows. In the case of negative energy balance in lactating sows, the amount of $C 2$ compounds is out of balance with the amount of C3 compounds. This is because of the abundant availability of $\mathrm{C} 2$ compounds from body reserves and the limited availability of $\mathrm{C} 3$ compounds due to a drain from the $\mathrm{C} 3$ pool for lactose production in milk. This restricts complete oxidation of fatty acids, which results in increased production of ketone bodies such as BHBA. When fat was supplemented in the diet, the amount of $C 2$ precursors increased further, resulting in an even greater disruption in the balance between $\mathrm{C} 2$ and $\mathrm{C} 3$ compounds (Figure 1a and 1b), and probably an increase in blood BHBA levels.

\section{Effect of starch or fat diets on metabolites during lactation}

In the last several decades much attention has been given to the nutritional signals affecting the hypothalamus, pituitary and/or the reproductive organs. Potential signals between nutrition and reproduction can be divided into hormones (insulin, leptin, growth hormone, thyroxine, triiodothyronine, glucocorticoids), growth factors (IGF-1, IGF-II) and metabolites (glucose, NEFA, $\mathrm{BHBA}$, urea). Several authors have reviewed these intermediates and their relationships with reproduction (Booth, 1990; Einarsson and Rojkittikhun, 1993; Cosgrove and Foxcroft, 1996; Prunier and Quesnel, 2000; Barb et al., 2001b). These relationships are briefly discussed in this review, but most attention is given to the effect of dietary energy source on the metabolites, NEFA, BHBA and urea.

\section{NEFAS}

Low feed intake and severe body weight loss during lactation are associated with increased levels of blood NEFAs. Effects were found in early (Kraetzl et al., 1998), mid (Messias de Bragança and Prunier, 1999) and late lactation (Prunier et al., 1993; Quesnel et al., 1998b). Weldon et al. (1994) found higher blood NEFA levels in lactating sows fed at a high level during gestation compared to sows fed at a normal level, which was probably due to low feed intake for the sows fed at a high level. These results were confirmed by Revell et al. (1998), who found higher blood levels of NEFA in fat postpartum sows compared to lean postpartum sows, which was probably due to the considerably lower feed intake of the fat sows during lactation. Hultén et al. (2002) divided sows into high and low catabolism groups based on average blood NEFA concentrations. Sows in the high catabolism group (relatively high blood NEFA concentration) lost considerably more weight during lactation than the low catabolism group. These studies demonstrated that high plasma NEFA concentrations reflect the metabolic state of lactating sows (Hultén et al., 2002). This is supported by results of Valros et al. (2003), who found relatively strong correlations between sow body weight loss and pre- and postfeeding plasma NEFA concentrations $(r=0.61$ and $r=0.75$, respectively).

Evidence for relationships between plasma NEFA concentration and reproduction in the pig is scarce, and in most cases, weak. Although not significant, Tokach et al. (1992) and Paterson and Pearce (1994) reported that plasma NEFA concentrations were higher during late lactation in sows with a prolonged WOI ( $>15$ days), compared to sows with a relatively short $\mathrm{WOI}(<$ 9 days). Mejia-Guadarrama et al. (2002) found a non-significant negative correlation between preprandial plasma NEFA concentration and the WOI. This is probably due to the weak negative correlation between plasma NEFA concentration and number of plasma $\mathrm{LH}$ pulses in late 
lactation (Tokach et al., 1992) or the day after weaning (Quesnel et al., 1998b). The latter study also demonstrated a negative correlation between plasma NEFA concentration on the day before weaning and the diameter of the 10 largest follicles on the day of weaning. Relationships between plasma NEFA concentration on the day of weaning or two days after weaning and follicle development were weak (Quesnel et al., 1998b). No correlations between preprandial plasma NEFA concentration and ovulation rate or number of viable embryos at day 30 of gestation were found by Mejia-Guadarrama et al. (2002). The question remains; is there a direct effect of NEFAs on reproduction or does the relationship between NEFA and reproduction only reflect the more severe catabolic state of the lactating sow, thereby indirectly affecting reproduction.

Studies on the effect of dietary energy source on plasma NEFA concentration largely produced comparable results. Plasma NEFA concentration was higher after feeding a fat-rich diet than after feeding a carbohydrate-rich diet in prepubertal gilts (Formigoni et al., 1996), in sows during gestation (Coffey et al., 1987; Newcomb et al., 1991) and in lactating sows (Coffey et al., 1987; Kveragas et al., 1988; Tilton et al., 1999b; Jones et al., 2002). Based on these studies, we concluded that carbohydrate-rich diets reduced the increase in plasma NEFA concentration during lactation, probably by reducing the amount of fat available from the feed, but also by reducing the amount of mobilized body fat.

If there is a direct negative effect of NEFAs on reproductive performance, fat-rich diets should also have a detrimental effect on reproductive performance of sows. The higher amount of NEFAs in the blood originates from dietary fat or from body reserve losses, as explained in Figure 1b. It is likely that the sow can not distinguish NEFAs originating from feed and NEFAs originating from body reserves. When fat-rich diets increase plasma NEFA concentration, it is likely that reproductive performance will be suppressed.

\section{$B H B A$}

In addition to NEFAs, BHBA is a metabolic indicator of energy balance in pigs. As summarized in Fig. 1, BHBA is especially produced when the complete oxidation pathway through acetyl$\mathrm{CoA}$ fails to process all triglycerides, because of a lack of sufficient oxaloacetate. Barb et al. (1997) found an increase in plasma NEFA and BHBA concentrations in prepubertal and mature gilts after acute feed deprivation. This is supported by the findings of Revell et al. (1998) who found greater blood $\mathrm{BHBA}$ levels in sows during lactation compared to gestation.

Dietary energy source clearly affects blood BHBA levels. Fat-rich diets increased blood BHBA levels in piglets (Lin et al., 1995), in sows during gestation (Newcomb et al., 1991) and in lactating sows (Jones et al., 2002) compared to control or carbohydrate-rich diets. Reduction of $\mathrm{BHBA}$ levels by carbohydrate-rich diets is supported by the fact that insulin reduced ketone body production (both BHBA and acetoacetate) in vitro in pig hepatocytes (Fernández-Fígares et al., 2004). Whether or not there is a relationship between BHBA levels in the blood and reproduction in pigs is largely unknown. Tokach et al. (1993) found no relationship between blood $\mathrm{BHBA}$ level and WOI or plasma $\mathrm{LH}$ pulse frequency during lactation.

\section{Urea}

Urea is a product of protein break-down. Blood urea concentration increases slightly during lactation (Nelssen et al., 1985; Baidoo et al., 1992; Hultén et al., 2002; Valros et al., 2003); probably due to the more severe catabolic state of the sow in late lactation. Mobilized body reserves not only consist of fat, but also of protein, which needs to be oxidized (Van der Peet-Schwering et al., 1998), and thereby, results in higher blood urea levels. Prunier et al. (1993) found an increase in blood urea levels only in primiparous sows fed at a low level during lactation $(2.5 \mathrm{~kg} /$ day $)$, but a 
A

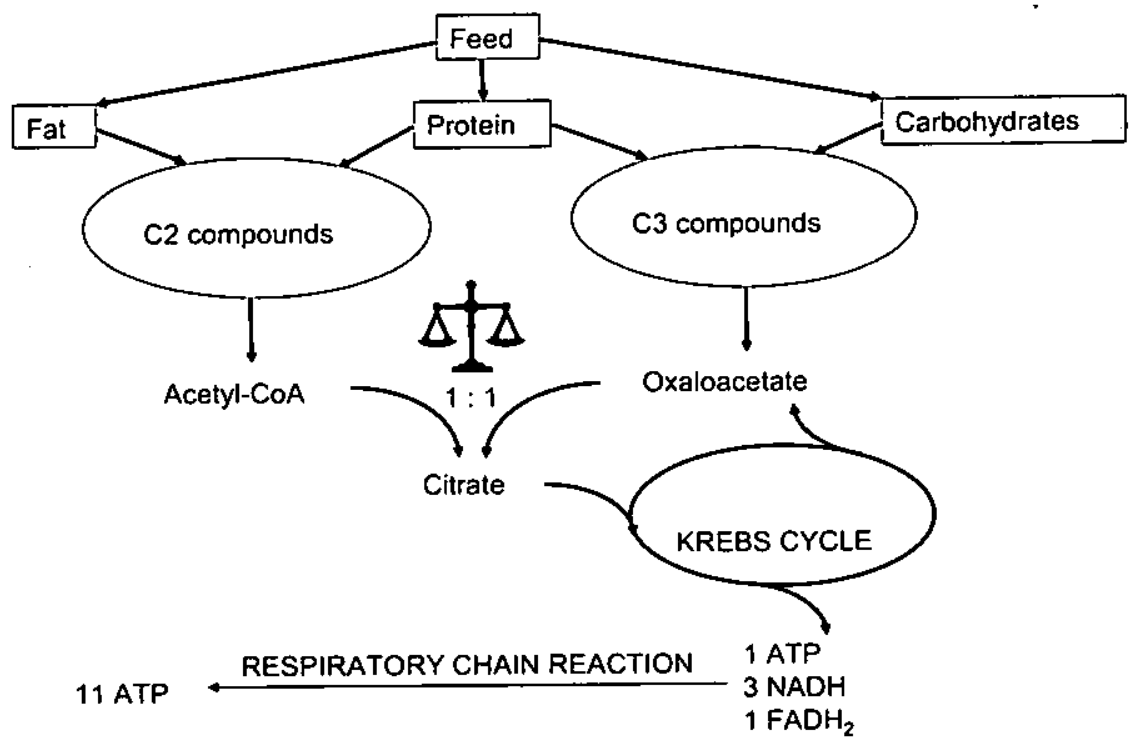

B

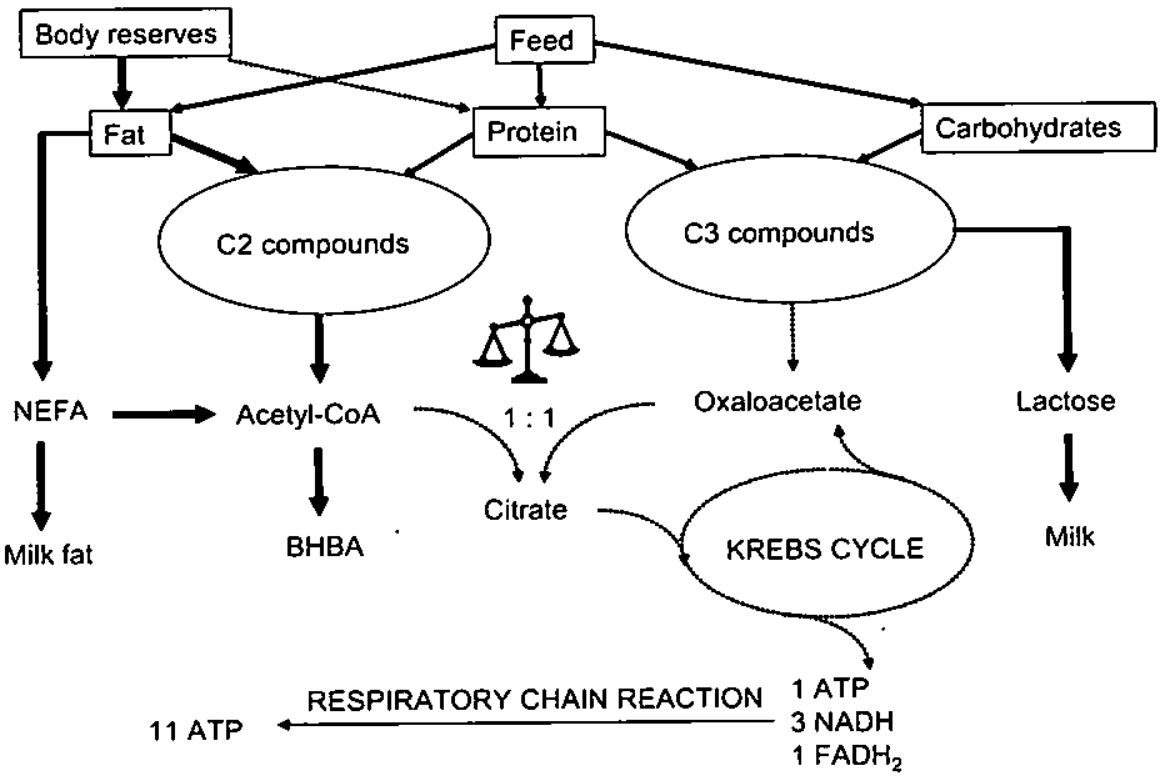

Fig. 1 Carbohydrate and lipid metabolism in a non-lactating sow (a) and a lactating sow in a negative energy balance (b). Weight of the arrows represents the amount of the several nutrients. $\mathrm{C} 2$ and $\mathrm{C} 3$ compounds - fragments containing 2 and $3 \mathrm{C}$-atoms, respectively; ATP - Adenosine Triphosphate; $\mathrm{NADH}$ - Nicotinamide Adenine Dinucleotide; FADH2 - Flavin Adenine Dinucleotide

slight decrease with progressing lactation when sows were fed at a high level $(5.5 \mathrm{~kg} / \mathrm{day})$. In the latter study, high feed intake in the lactating sow resulted in lower plasma urea concentration compared to low feed intake. This was supported by Hultén et al. (1993) who found higher plasma urea levels during lactation in sows that were fat prepartum $(18.8 \mathrm{~mm}$ backfat) compared to sows that were lean prepartum $(12.9 \mathrm{~mm}$ backfat); probably due to a lower lactational 
feed intake for the fat sows. However, Rojkittikhun et al. (1993b) did not find higher plasma urea levels in sows in a more severe catabolic state. Sows that lost more than $25 \mathrm{~kg}$ of body weight during lactation had plasma urea levels comparable to sows which lost less than $25 \mathrm{~kg}$ of body weight. On the other hand, Sterning et al. (1997) found a significant positive correlation between relative body weight loss during lactation and plasma urea concentration in late lactation, whereas Valros et al. (2003) found a significant negative correlation between sow body weight loss in early lactation and urea concentration. These ambiguous results can possibly be explained by the protein content of the feeds used.

Studies of the effects of dietary energy source on plasma urea levels in sows are limited. Newcomb et al. (1991) found no effect of dietary energy source (starch, soybean oil, medium chain triglycerides) on plasma urea levels in late gestation, but Nelssen et al. (1985) and Jones et al. (2002) found higher plasma urea concentrations in lactating sows fed a fat-rich diet compared to a carbohydrate-rich diet. Ponter et al. (1994) also found higher plasma urea levels in piglets fed a fat-rich diet compared to a carbohydrate-rich diet, suggesting that protein breakdown is higher in animals on a fat-rich diet. Based on these results, the question becomes; what is the reason for higher blood urea concentration in sows fed a fat-rich diet? In general, blood urea concentration was positively related to a more severe catabolic state. Furthermore, pigs fed a fat-rich diet had a limitation in their dietary supply of glucose (C3) and consequently tried to generate glucose via gluconeogenesis. Gluconeogenic amino acids and glycerol are precursors of glucose (Jones et al., 2002). Oxidation of protein to supply the glucogenic amino acids required for glucose synthesis results in a higher concentration of the by-product, urea, in the blood.

Effects of high blood urea concentration on reproduction of sows have rarely been described. Tokach et al. (1992) found a very weak negative correlation between blood urea concentrations and plasma $\mathrm{LH}$ pulse frequency in late lactation. In dairy cattle, relationships between urea and reproduction are clearer than in sows (for review see Butler, 1998).

\section{Effects of dietary energy source on metabolic hormones and growth factors}

In addition to metabolites, metabolic hormones and growth factors are influenced by nutrition and act as intermediaries between nutrition and reproduction. This section focuses on the role of insulin and IGF- $I$ in the relationship between nutrition and reproductive function. Attention is given only to insulin and IGF-I because these are affected by dietary energy source.

\section{Insulin}

Several studies showed that insulin might be an intermediary between nutrition and reproduction; acting at both the hypothalamus-pituitary and ovarian level. For example, Tokach et al. (1992), Koketsu et al. (1996) and Quesnel et al. (1998b) found correlations between plasma insulin concentration and plasma LH pulse frequency during and after lactation in sows. Furthermore, exogenous insulin increased plasma LH pulse frequency in gilts (Cox et al., 1987). The observation that $\mathrm{LH}$ and $\mathrm{FSH}$ release by cultured rat pituitary cells were enhanced after insulin administration (Adashi et al., 1981) also supports a role for insulin at the pituitary. Insulin receptors are present in the ovary (Ladenheim et al., 1984) and administration of insulin increased differentiation of cultured granulosa cells (May and Schomberg, 1981; Poretsky and Kalin, 1987). Finally, exogenous insulin in gilts decreased the number of atretic follicles (Matamoros et al., 1990) and increased the ovulation rate (Cox et al., 1987).

The effect of dietary energy source on plasma insulin concentration is very clear. Carbohydrate-rich diets increased plasma insulin concentration more than fat-rich diets, in both non- 
lactating and lactating pigs (Newcomb et al., 1991; Ponter et al., 1991; Kemp et al., 1995; Van den Brand et al., 1998, 2000a; Jones et al., 2002). The pattern of insulin secretion was largely influenced by the type of carbohydrate or fat. Van den Brand et al. (1998) demonstrated a considerably higher plasma insulin peak level after feeding dextrose combined with maize starch than after feeding maize starch alone. Furthermore, plasma insulin level remained higher during $4.5 \mathrm{~h}$ after feeding the dextrose rich diet. Insulin response may be affected by the fatty acid composition of fat-rich diets. In cattle, poly-unsaturated fatty acids increased postprandial insulin levels more than saturated fatty acids (Thomas and Williams, 1996; Thomas et al., 1997). Comparable results should be expected in lactating sows, but controlled experiments on the effect of different fat sources on blood insulin concentrations, to our knowledge, have not been conducted in sows. It is clear that carbohydrate-rich diets increase post-prandial blood insulin level more than fat-rich diets. The amount of increase depends on the carbohydrate source and possibly on the fat source in the diet. We suggest that diets, which enhance plasma insulin concentration, may be a tool to improve reproductive performance.

\section{IGF-I}

Blood IGF-I concentrations in lactating sows depend on feed intake. High feed intake during lactation resulted in a higher blood IGF-I level (Quesnel et al., 1998b; Zak et al., 1998; Messias de Bargança and Prunier, 1999; Van den Brand et al., 2001a). Restricted feed intake during one week of lactation decreased blood IGF-I concentration (Zak et al., 1997a), suggesting a rapid effect of feed intake on blood IGF-I concentration. In prepubertal and mature gilts, acute feed deprivation markedly decreased blood IGF-I concentration (Barb et al., 1997; 2001a). Blood IGF-I concentration was related to blood insulin ( $V$ an den Brand et al., 2001a), leptin and GH concentrations (Barb et al., 2001a,b), suggesting that IGF-I is an important intermediary among nutrition, metabolism and reproduction. Potential relationships between IGF-I and pituitary hormones related to reproduction were described by Barb et al. (2001b). Additionally, Van den Brand et al. (2001a) found positive relationships between IGF-I concentration on the day before weaning or the day of weaning and plasma LH puise frequency on the day of weaning and the preovulatory LH surge.

The role of dietary energy source on IGF-I secretion has rarely been investigated in the pig. Van den Brand et al. (2001a) found higher plasma IGF-I concentrations at the end of lactation and the day of weaning after feeding a carbohydrate-rich diet than after feeding a fat-rich diet. However, after weaning, blood IGF-I concentration increased to similar levels, regardless of dietary energy source and lactational feed intake. This agrees with data from Caroll et al. (1996), Messias de Bragança and Prunier (1999) and Van den Brand et al. (2001b). They showed that blood IGF-I levels were lower in feed restricted sows during lactation, than in sows fed ad libitum. However, feed restricted sows restored their blood IGF-I concentration within a few days post-weaning to levels comparable to those in sows fed ad libitum during lactation. It seems that dietary energy source does not affect IGF-I concentration when sows are in an anabolic status. Gaughan et al. (1996) found no differences in IGF-I levels among gilts fed a fat-rich diet or a fat-poor diet ad libitum. Plasma insulin concentration was correlated with IGF-I concentration in sows in a catabolic status (Van den Brand et al., 2001a), and it appears in this situation, that insulin facilitated IGF-I production by the liver (Daughaday et al., 1976; Johnson et al., 1989; Butler et al., 2003).

\section{Effects of dietary energy source on reproductive performance}

$L H$, oestradiol, and progesterone secretion

The number of studies regarding the effects of dietary energy source on reproductive hormones 
in sows is limited. Van den Brand et al. (2000a) used two levels of feed intake, and within each feeding level, fed a fat-rich or a carbohydrate-rich diet to lactating primiparous sows. Plasma LH pulse frequency during lactation was higher in sows given the higher level of feed than in sows given the lower level of feed $(P=0.04)$. In addition, sows fed the carbohydrate-rich diet tended to have a higher plasma LH pulse frequency than sows fed the fat-rich diet (Fig. $2 ; \mathrm{P}=0.06$ ). There was no effect of lactational dietary energy source on plasma LH pulse frequency on the day of weaning (6.79 vs 7.61 per $12 \mathrm{~h}$, for the fat and starch-rich diet, respectively, $P=0.31$ ). In the same sows, there was no effect of dietary energy source on post-weaning oestradiol and progesterone profiles as well as on the preovulatory LH surge (Van den Brand et al., 2000c). However, in multiparous sows, Kemp et al. (1995) found higher plasma oestradiol concentrations, a higher preovulatory $\mathrm{LH}$ surge and higher plasma progesterone concentrations when feeding a starch-rich diet compared to a fat-rich diet. This suggests that, in sows in a less severe negative energy balance, starch-rich diets stimulated reproductive endocrinology both at the pituitary and ovary. When sows were in a more severe negative energy balance, the effects of dietary energy source on reproductive endocrinology seemed to be limited.

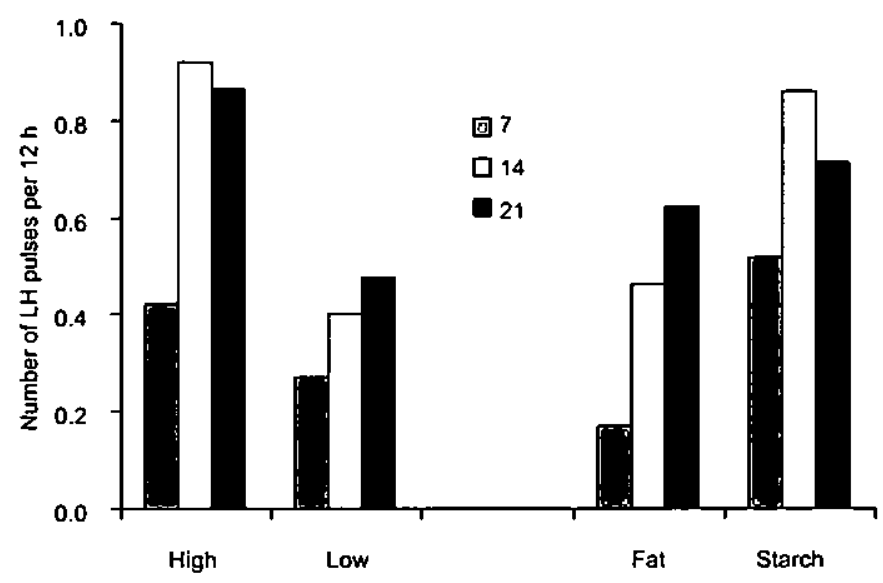

Fig. 2 Effect of feeding a fat or starch-rich diet at two feeding levels on $\mathrm{LH}$ pulse frequency during day 7,14 and 21 of lactation. Overall SEM $=0.20$. Feed intake: $P=0.04$; Dietary energy source: $\mathrm{P}=0.06$ (Van den Brand et al., 2000a).

Follicle development, WOI and ovulation rate

Ziêcik et al. (2002) found no effect of dietary energy source (starch, glucose or fat) on number and size of healthy and atretic follicles in gilts. Van den Brand et al. (2000a) found no differences in follicle size on day 2 after weaning when feeding a fat or carbohydrate-rich diet during and after lactation. However, when only sows that came into oestrus after weaning were taken into account, follicle size tended to be higher in sows fed the carbohydrate-rich diet (3.2 vs 3.8 $\mathrm{mm} ; \mathrm{P}=0.06$ ). The percentage of sows, which came into oestrus within 10 days after weaning, was similar for both dietary energy sources. In another experiment, in which the carbohydraterich or fat-rich diets were fed only after weaning, more primiparous sows in the carbohydraterich group entered postpartum oestrus earlier than those in the fat-rich group (Van den Brand et al., 2001b; $\mathrm{P}=0.04$ ). Sows in this experiment lost $13 \%$ of their body weight, suggesting that, in sows that are predisposed to a prolonged WOI, carbohydrate-rich diets help to overcome this 
problem. In most cases, the WOI was not affected by dietary energy source fed during lactation (Rodriguez-Marquez and Cuaron, 1990; Johnston et al., 1994; Van den Brand et al., 2000a; Jones et al., 2002), although Van den Brand et al. (2000a) showed that the WOl was $22 \mathrm{~h}$ shorter in sows fed a starch-rich diet at a low feeding level during lactation than in sows fed the fat-rich diet (130 vs $152 \mathrm{~h}$, respectively; not significant).

Ovulation rate was greater in gilts fed a molasses rich diet compared to a control diet or a soy oil rich diet (14.5 vs 12.1 vs 11.9, respectively; Rodriguez-Marquez and Cuaron, 1990) and Cox et al. (1987) found that exogenous insulin increased the ovulation rate in gilts. However, this could not be confirmed in other studies using exogenous insulin (Rojkittikhun et al., 1993a; Quesnel and Prunier, 1998). Van den Brand et al. (2000a) also found no effect of dietary energy source during lactation on subsequent ovulation rate in primiparous sows (17.0 vs 17.7 for the starch and fat-rich diet, respectively; $P=0.50$ ). Based on these results, we conclude that carbohydrate-rich diets may have positive effects on reproduction traits, however, these effects are not very pronounced.

\section{Conclusion}

Increasing energy intake by addition of fat to the diet of lactating sows has limited or even negative effects on the reproductive performance of sows. Three pathways reacted negatively when feeding fat-rich diets. First, increasing dietary fat increased milk fat output, but also stimulated body fat loss. Second, fat-rich diets increased blood metabolite levels, which are possibly negatively related to reproductive performance. Third, fat-rich diets depressed secretion of insulin and IGF-1, which are directly or indirectly positively related with the concentration of reproductive hormones. Thus, we suggest looking to other ways to increase energy intake or to decrease body weight loss during lactation. Management factors to support feed intake, such as housing temperature, water intake and prevention of overfeeding in early lactation have more beneficial effects on reproductive performance than feeding fat-rich diets.

\section{References}

Adashi EY, Hsueh AJW and Yen SSC (1981) Insulin enhancement of luteinizing hormone and follicle-stimulating hormone release by cultured pituitary cells Endocrinology 108 1441-1449

Auldist DE, Morrish L, Eason P and King RH (1998) The influence of litter size on milk production of sows Animal Science 67 333-337

Auldist DE, Carlson D, Morrish L, Wakeford CM and King RH (2000) The influence of suckling interval on milk production of sows Journal of Animal Science 78 2026-2031.

Averette LA, Odle I, Monaco MH and Donovan SM (1999) Dietary fat during pregnancy and lactation increases milk fat and insulin-like growth factor I concentrations and improves neonatal growth rates in swine Journal of Nutrition 129 2123-2129

Babinszky L. (1992) Energy metabolism and lactation performance of primiparous sows as affected by dietary fat and vitamin E PhD Thesis Wageningen The Netherlands

Baidoo SK, Lythgoe ES, Kirkwood RN, Aherne FX and Foxcroft GR (1992) Effect of lactation feed intake on endocrine status and metabolite levels in sows Canadian Journal of Animal Science 72 799-807
Barb CR, Kraeling RR, Rampacek GB and Dove CR (1997) Metabolic changes during the transition from the fed to the acute feed-deprived state in prepuberal and mature gilts Journal of Animal Science 75 781-789

Barb CR, Barrett JB, Kraeling RR and Rampacek GB (2001a) Serum leptin concentrations, luteinizing hormone and growth hormone secretion during feed and metabolic fuel restriction in the prepuberal gilt Domestic Animal Endocrinology 20 47-63.

Barb CR, Kraeling RR and Rampacek GB (2001b) Nutritional regulators of the hypothalamic-pituitary axis in pigs Reproduction Supplement 58 1-15

Booth PJ (1990) Metabolic influences on hypothalamicpituitary-ovarian function in the pig Journal of Reproduction and Fertility Supplement 40 89-100

Boyd, RD, Kensinger RS, Harrell RJ and Bauman DE (1995) Nutrient uptake and endocrine regulation of milk synthesis by mammary tissue of lactating sows Journal of Animal Science 73 36-56

Butler, ST, Marr AL, Pelton SH, Radcliff RP, Lucy MC and Butler WR (2003) Insulin restores $\mathrm{GH}$ responsiveness during lactation-induced negative energy balance in dairy cattle: effects on expression of IGF. $\mathrm{I}$ and $\mathrm{CH}$ receptor $1 \mathrm{~A}$ Journal of Endocrinology 176 205-217 
Butler, WR (1998) Review: Effect of protein nutrition on ovarian and uterine physiology in dairy cattle Journal of Dairy Science 81 2533-2539

Caroll CM, Lynch PB, Boland MP, Spicer LJ, Austin FH, Leonard N, Enright WJ and Roche JF (1996) The effects of food intake during lactation and post weaning on the reproductive performance and hormone and metabolite concentration of primiparous sows Animal Science 63 297-306

Coffey MT, Yates IA and Combs GE (1987) Effects of feeding sows fat or fructose during late gestation and lactation Journal of Animal Science 65 1249-1256

Cosgrove JR and Foxcroft GR (1996) Nutrition and reproduction in the pig: ovarian aetiology Animal Reproduction Science 42 131-141

Cox NM, Stuart M], Althen TG, Bennett WA and Miller HW (1987) Enhancement of ovulation rate in gilts by increasing dietary energy and administering insulin during follicular growth Journal of Animal Science 64 507-516

Daughaday WH, Mueller MC and Phillips LS (1976) The effect of insulin and growth hormone on the release of somatomedin by the isolated rat liver Endocrinology 98 1214-1219

Drochner W (1989) Einflüsse von Fettzulagen an Sauen auf Aufzuchtleistung und Fruchtbarkeit [Effect of fat addition to sows on rearing performance and fertilityl Übersicht Tierernährung 17 99-138.

Dourmad JY, Etienne M, Prunier A and Noblet / (1994) The effect of energy and protein intake of sows on their longevity: a review Livestock Production Science 4087.97

Einarsson S and Rojkittikhun T (1993) Effects of nutrition on pregnant and lactating sows Journal of Reproduction and Fertility Supplement 48 229-239

Fernández-Fígares I, Shannon AE, Wray-Cahen D and Caperna TJ (2004) The role of insulin, glucagon, dexamethasone, and leptin in the regulation of ketogenesis and glycogen storage in primary cultures of porcine hepatocytes prepared from $60 \mathrm{~kg}$ pigs Domestic Animal Endocrinology 27 125-140

Formigoni A, Parmeggiani A, Spinaci $M$, Govoni $N$ and Galeati G (1996) Influence of the energy source on pulsatile LH secretion in prepubertal gilts p 576 Proceedings of the 14th IPVS Congress, Bologna, Italy

Gaughan, JB, Cameron RDA, Dryden GMcL and Young BA (1996) Influence of dietary fat on cholesterol, insulin like growth factor-I (ICF-1), insulin, glucose and reproductive development in gilts. Journal of Animal Science 74 Supplement 1233 (Abstract)

Hultén F, Neil M, Einarsson S and Hảkansson J (1993) Energy metabolism during late gestation and lactation in multiparous sows in relation to backfat thickness and the interval from weaning to first oestrus Acta Veterinaria Scandinavica 34 9-20

Hultén F, Valros, A, Rundgren M and Einarsson S (2002) Reproductive endocrinology and postweaning performance in the multiparous sow Part 1. Influence of metabolic status during lactation Theriogenology $\mathbf{5 8}$ 1502-1517
Johnson TR, Blossey BK, Denko CW and Ilan J (1989) Expression of insulin-like growth factor-l in cultured hepatocytes: Effects of insulin and growth hormone. Molecular Endocrinology 3 580-587

Johnston LJ, Pettigrew JE, Wilson ME, Walker RD and Crooker BA (1994) Influence of dietary molasses on reproductive performance of lactating sows journal of Animal Science 77 Supplement 1334 (Abstract)

Jones GM, Edwards SA, Sinclair AG, Gebbie FE, Rooke JA, Jagger S and Hoste S (2002) The effect of maize starch or soy-bean oil as energy sources in lactation on sow and piglet performance in association with sow metabolic state around peak lactation Animal Science $75 \quad 57.66$

Kemp B (1998) Lactational effects on the endocrinology of reproduction In The lactating sow pp 241-257 Eds MWA Verstegen, PJ Moughan and JW Schrama. Wageningen Pers, Wageningen

Kemp B, Soede NM, Helmond FA and Bosch MW (1995) Effects of energy source in the diet on reproductive hormones and insulin during lactation and subsequent estrus in multiparous sows Journal of Animal Science 73 3022-3029

King RH, Pettigrew JE, McNamara JP, McMurthy JP, Henderson TL, Hathaway MR and Sower AF (1996) The effect of exogenous prolactin on lactation performance of first-litter sows given protein-deficient diets during the first pregnancy Animal Reproduction Science 41 37-50

Kirkwood RN, Lythgoe ES and Aherne FX (1987a) Effect of lactation feed intake and gonadotropin-releasing hormone on the reproductive performance of sows Canadian Journal of Animal Science 67 715-719

Kirkwood RN, Baidoo SK, Aherne FX and Sather AP (1987b) The infiluence of feeding level during lactation on the occurrence and endocrinology of the postweaning estrus in sows Canadian Journal of Animal Science $67405-415$

Koketsu $Y$ and Dial GD (1997) Factors influencing the postweaning reproductive performance of sows on commercial farms Theriogenology 47 1445-1461

Koketsu Y, Dial GD, Pettigrew JE, Marsh WE and King VL (1996) Influence of imposed feed intake patterns during lactation on reproductive performance and on circulating levels of glucose, insulin, and luteinizing hormone in primiparous sows Journal of Animal Science 74 1036-1046

Kraetzl WD, Zimmer C, Schneider D and Schams D (1998) Secretion pattern of growth hormone, prolactin, insulin and insulin-like growth factor-1 in the periparturient sow depending on the metabolic state during lactation Animal Science 67 339-347

Kveragas CL, Seerley RW, Martin RJ and Vandergrift WL (1988) Maternal feeding of glucose, fructose or fat and its effects on sows and pigs Nutrition Reports International 37 665.674

Ladenheim RG, Tesone $M$ and Charreau EH (1984) Insulin action and characterization of insulin receptors in rat luteal cells Endocrinology 115 752-756

Lauridsen C and Danielsen V (2004) Lactational dietary 
fat levels and sources influence milk composition and performance of sows and their progeny Livestock Production Science 91 95-105

Lin CL, Chiang SH and Lee HF (1995) Causes of reduced survival of neonatal pigs by medium-chain triglycerides: Blood metabolite and behavioural activity approaches Journal of Animal Science 73 2019-2025

Matamoros IA, Cox NM and Moore AB (1990) Exogenous insulin and additional energy affect follicular distribution, follicular steroid concentrations, and granulosa cell human chorionic gonadotropin binding in swine Biology of Reproduction 431.7

May JV and Schomberg DW (1981) Granulosa cell differentiation in vitro: Effect of insulin on growth and functional integrity Biology of Reproduction 25 421431

McNamara JP and Pettigrew JE (2002) Protein and fat utilization in lactating sows: I. Effects on milk production and body composition Journal of Animal Science $80 \quad 2442-2451$

Mejia-Guadarrama CA, Pasquier A, Dourmad JY, Prunier $A$ and Quesnel H (2002) Protein (lysine) restriction in primiparous lactating sows: Effects on metabolic state, somatotropic axis, and reproductive performance after weaning Journal of Animal Science $\mathbf{8 0}$ 3286-3300

Messias de Brangança M and Prunier A (1999) Effects of low feed intake and hot environment on plasma profiles of glucose, nonesterified fatty acids, insulin, glucagon, and IGF-1 in lactating sows Domestic Animal Endocrinology 16 89-101

Nelssen IL, Lewis Al, Peo Jr AJ and Moser BD (1985) Effect of source of dietary energy and energy restriction during lactation on sow and litter performance Journal of Animal Science 60 171-178

Newcomb MD, Harmon DL, Nelssen JL, Thulin AJ and Allee GL (1991) Effect of energy source fed to sows during late gestation on neonatal blood metabolite homeostasis, energy stores and composition Journal of Animal Science 69 230-236

Poretsky L and Kalin MF (1987) The gonadotropic function of insulin Endocrine reviews 8 132-141

Paterson AM and Pearce GP (1994) Plasma hormone and metabolite concentrations and the interval from weaning to oestrus in primiparous sows Animal Reproduction Science $36 \quad 261-279$

Pettigrew JE and Moser RL (1991) Fat in swine nutrition. In Swine Nutrition pp 133-145 Eds ER Miller, DE Ullrey and A) Lewis. Butterworth-Heineman, Boston

Ponter AA, Salter DN, Morgan LM and Flatt PR (1991) The effect of energy source and feeding level on the hormones of the entero-insular axis and plasma glucose in the growing pig British Journal of Nutrition 66 187-197

Ponter AA, Cortamira NO, Sève B, Salter DN and Morgan LM (1994) The effects of energy source and tryptophan on the rate of protein synthesis and on hormones of the entero-insular axis in the piglet British Journal of Nutrition 71 661-674
Prunier A and Quesnel H (2000) Nutritional influences on the hormonal control of reproduction in female pigs Livestock Production Science 63 1-16

Prunier A, Dourmad JY and Etienne M (1993) Feeding level, metabolic parameters and reproductive performance of primiparous sows Livestock Production Science 37 185-196

Quesnel $H$ and Prunier A (1998) Effect of insulin administration before weaning on reproductive performance in feed-restricted primiparous sows Animal Reproduction Science 51 119-129

Quesnel H, Pasquier A, Mounier AM and Prunier A (1998a) Influence of feed restriction during lactation on gonadotropic hormones and ovarian development in primiparous sows Journal of Animal Science $76856-863$

Quesnel H, Pasquier, A, Mounier AM, Louveau I and Prunier A (1998b) Influence of feed restriction in primiparous lactating sows on body condition and metabolic parameters Reproduction Nutrition Development 38 261-274

Ramanau A, Kluge H, Spilke J and Eder K (2004) Supplementation of sows with l-carnitine during pregnancy and lactation improves growth of the piglets during the suckling period through increased milk production Journal of Nutrition 134 86-92

Renaudeau D and Noblet I (2001) Effects of exposure to high ambient temperature and dietary protein level on sow milk production and performance of piglets Journal of Animal Science 79 1540-1548

Revell DK, Williams IH, Mullan BP, Ranford IL and Smits RJ (1998) Body composition at farrowing and nutrition during lactation affect the performance of primiparous sows: I. Voluntary feed intake, weight loss, and plasma metabolites Journal of Animal Science 76 1729-1737

Rodriguez-Marquez MC and Cuaron IA (1990) Dietary energy source on ovulation in swine Journal of Animal Science 68 Supplement 1367 (Abstract)

Rojkittikhun $T$, Einarsson S, Zilinskans $H$, Edqvist L-E, Uvnäs-Moberg K and Lundeheim N (1993a) Effects of insulin administration at weaning on hormonal patterns and reproductive performance in primiparous sows Journal of Veterinary Medicine A 40 161-168

Rojkittikhun T, Einarsson S, Uvnäs-Moberg $K$ and Edqvist L-E (1993b) Body weight loss during lactation in relation to energy and protein metabolism in standardfed primiparous sows Journal of Veterinary Medicine A 40 249-257

Schoenherr WD, Stahly TS and Cromwell GL (1989) The effects of dietary fat or fiber addition on yield and composition of milk form sows housed in a warm or hot environment Journal of Animal Science 67 482495

Sterning M, Hultén F, Holst $H$, Einarsson $S$ and Andersson $K$ (1997) Relationships between health and weight loss during lactation and between health and ability to return to oestrus after weaning in primiparous sows Journal of Veterinary Medicine A 44 301-311 Thomas MG and Williams GL (1996) Metabolic hor- 
mone secretion and FSH-induced superovulatory responses of beef heifers fed dietary fat supplements containing predominantly saturated or polyunsaturated fatty acids Theriogenology $45 \quad 451-458$

Thomas MG, Bao B and Williams GL (1997) Dietary fats varying in their fatty acid composition differentially influence follicular growth in cows fed isoenergetic diets Journal of Animal Science 75 2512-2519

Tilton S1, Miller PS, Lewis A), Reese DE and Ermer PM (1999a) Addition of fat to the diets of lactating sows: I. Effects on milk production and composition and carcass composition of the litter at weaning lournal of Animal Science 77 2491-2500

Tilton SL, Miller PS, Lewis A], Reese DE and Ermer PM (1999b) Addition of fat to the diets of lactating sows: II. Effects on hormone-sensitive lipase activity, energy mobilization in response to epinephrine, and plasma insulin and glucose concentrations Journal of Animal Science 77 2501-2509

Tokach MD, Pettigrew JE, Dial GD, Wheaton JE, Crooker BA and Johnston LJ (1992) Characterization of luteinizing hormone secretion in the primiparous, lactating sow: Relationship to blood metabolites and return-to-estrus interval Journal of Animal Science 70 2195-2201

Tokach MD, Pettigrew JE, Frey RS, Hathaway MR and Dial GD (1993) Relationship of IGF-I and a-hydroxy butyrate to $\mathrm{LH}$ secretion and return-to-estrus interval in primiparous lactating sows. Book of Abstracts 4e ICPR p 99, Missouri, Columbia, USA

Toner MS, King RH, Dunshea FR, Dove $H$ and Atwood CS (1996) The effect of exogenous somatotropin on lactation performance of first-litter sows Journal of Animal Science 74 167-172

Valros A, Rundgren M, Špinka M, Saloniemi $H$, Rydhmer 1. Hultén F, Uvnäs-Moberg K, Tománek M, Krejcí P and Algers B (2003) Metabolic state of the sow, nursing behaviour and milk production Livestock Production Science 79 155-167

Van den Brand $H$, Soede NM, Schrama JW and Kemp B (1998) Effects of dietary energy source on plasma glucose and insulin concentration in gilts Journal of Animal Physiology and Animal Nutrition 79 27-32

Van den Brand H, Dieleman SJ, Soede NM and Kemp B (2000a) Dietary energy source at two feeding levels during lactation of primiparous sows: I. Effects on glucose, insulin, and luteinizing hormone and on follicle development, weaning-to-estrus interval, and ovulation rate Journal of Animal Science 78 396-404

Van den Brand H, Heetkamp MJW, Soede NM, Schrama JW and Kemp B (2000b) Energy balance of lactating primiparous sows as affected by feeding level and dietary energy source Journal of Animal Science 78 1520-1528
Van den Brand $H$, Soede NM and Kemp B (2000c) Dietary energy source at two feeding levels during lactation of primiparous sows: II. Effects on periestrus hormone profiles and embryonal survival Journal of Animal Science 78 405-411

Van den Brand H, Prunier A, Soede NM and Kemp B (2001a) In primiparous sows, plasma insulin-like growth factor-l is associated with luteinizing hormone and can be affected by lactational feed intake and dietary energy source Reproduction Nutrition Development 41 27-39

Van den Brand $\boldsymbol{H}$, Langendijk P, Soede NM and Kemp B (2001b) Effects of postweaning dietary energy source on reproductive traits in primiparous sows Journal of Animal Science 79 420-426

Van der Peet-Schwering CMC, Swinkels JWGM and Den Hartog LA (1998) Nutritional strategy and reproduction In The lactating sow pp 221-240 Eds MWA Verstegen, PJ Moughan and JW Schrama. Wageningen Pers, Wageningen

Vesseur PC, Kemp B and Den Hartog LA (1994) Factors affecting the weaning to oestrus interval in the sow Journal of Animal Physiology and Animal Nutrition 72 225-233

Weldon WC, Lewis AJ, Louis GF, Kovar JL, Giesemann MA and Miller PS (1994) Postpartum hypophagia in primiparous sows: I. Effects of gestation feeding level on feed intake, feeding behaviour, and plasma metabolic concentration during lactation Journal of Animal Science 72 387-394

Williams IH (1998) Nutritional effects during lactation and during the interval from weaning to oestrus in The lactating sow pp 159-181 Eds MWA Verstegen, PJ Moughan and JW Schrama. Wageningen Pers, Wageningen

Zak LJ, Cosgrove IR, Aherne FX and Foxcroft GR (1997a) Pattern of feed intake and associated metabolic and endocrine changes differentially affect postweaning fertility in primiparous lactating sows Journal of Animal Science 75 208-216

Zak LJ, Xu X, Hardin RT and Foxcroft GR (1997b) impact of different patterns of feed intake during lactation in the primiparous sow on follicular development and oocyte maturation Journal of Reproduction and Fertility 110 99-106

Zak LI, Williams IH, Foxcroft GR, Pluske JR, Cegielski AC, Clowes EJ and Aherne FX (1998) Feeding lactating primiparous sows to establish three divergent metabolic states: I. Associated endocrine changes and postweaning reproductive performance Journal of Animal Science 76 1145-1153

Ziêcik AJ, Kapelañski W, Zaleska M and Riopérez J (2002) Effect of diet composition and frequency of feeding on postprandial insulin level and ovarian follicular development in prepubertal pigs Journal of Animal and Feed Sciences $11471-483$ 